\title{
Representasi Pekerja Wanita dalam Serial Drama Hope: Kitai Zero no Shinnyu Shain
}

\author{
Nabila Vina Fairuzzahra*, Susy Ong \\ ${ }^{*}$ Kajian Wilayah Jepang, Universitas Indonesia, Depok, Indonesia \\ email: nabila_vf@yahoo.co.id*,susy.ong66@gmail.com
}

DOI: $10.20884 / 1 . j l i t e r a .2020 .2 .1 .3430$

\begin{abstract}
Gender inequality has been an issue in Japanese employment. This issue is then being reflected by media in Japan through drama series such as Hope: Kitai Zero no Shinnyu Shain. Hope: Kitai Zero no Shinnyu Shain told about a rookie worker and his comerades whom tried so hard to work in trading company. This research aimed to identify and explain how female workers were represented in Hope: Kitai Zero no Shinnyu Shain drama series through the characterization of Kazuki Akane and Shiraishi Ryoko. This research is qualitative descriptive research. To analyze data, this research used semiotic approach by Roland Barthes. The result showed that female workers in the drama series were represented as 1) ones whose main role gender was in domestic sphere; 2) ones who supported male counterparts; 3) subordinates who had lower position than male counterparts. Therefore, this representation reflected gender inequality that occured between male workers and female workers.
\end{abstract}

\section{Keywords:}

Representation; Japanese female workers; Semiotic;

Japanese drama series

Article Info:

First received:

25 October 2020

Available online:

30 November 2020

\section{PENDAHULUAN}

Dewasa ini, isu mengenai gender telah menjadi suatu masalah sosial di Jepang. Sebab, meskipun saat ini Jepang telah menjadi negara maju, tingkat kesetaraan antara laki-laki dan wanita di Jepang sangat rendah. Salah satunya dapat dijumpai dalam aspek ketenagakerjaan Jepang. Ketidaksetaraan gender dalam sistem ketenagakerjaan di Jepang diketahui muncul pada zaman Meiji.

Industrialisasi yang terjadi pada zaman Meiji menyebabkan terjadinya perekrutan secara besar-besaran terhadap wanita-wanita muda yang tinggal di daerah pedesaan dan pegunungan untuk bekerja di pabrik tekstil (Gordon, 2003: 100; Watanabe, 2011: 28). Para wanita muda tersebut berasal dari latar belakang keluarga yang miskin, sehingga bekerja di pabrik dianggap sebagai jalan bagi mereka untuk mendapatkan penghasilan tambahan. Namun, para wanita muda tersebut memiliki jam kerja yang lebih panjang daripada pekerja laki-laki, tetapi upah yang mereka terima justru lebih rendah daripada pekerja laki-laki (Gordon,
2003: 100). Hal ini menunjukkan bahwa perubahan sosioekonomi masyarakat Jepangdari masyarakat agraria rural menjadi masyarakat industri urban-menjadi faktor terjadinya ketidaksetaraan gender dalam sistem ketenagakerjaan Jepang.

Lalu, bila melihat fenomena ketenagakerjaan Jepang di era saat ini, dapat diketahui bahwa meskipun persentase populasi pekerja wanita di Jepang mengalami kenaikan dalam beberapa tahun terakhir, tingkat partisipasi pekerja wanita masih lebih rendah daripada tingkat partisipasi kerja laki-laki. Pada tahun 2019, persentase populasi pekerja wanita mencapai 44\% (World Bank, 2020). Angka ini mengalami peningkatan sebesar $1,4 \%$ bila dibandingkan dengan tahun 2014 (World Bank, 2020). Namun, tingkat partisipasi kerja wanita pada tahun 2019 hanya sekitar 52,7\%, sedangkan tingkat partisipasi kerja laki-laki mencapai 71,3\% (World Bank, 2020). Dengan kata lain, tingkat partisipasi kerja wanita lebih rendah sekitar 19\% daripada laki-laki. 
Di samping itu, meskipun angka populasi pekerja wanita meningkat, sebagian dari pertambahan angka tersebut mengacu pada populasi pekerja part timer. Pekerja part timer adalah pekerja yang memiliki jam kerja lebih pendek daripada pekerja tetap dan menerima upah yang dibayarkan per jam (Shinotsuka, 1994: 110). Pada tahun 2012, persentase populasi part timer wanita di Jepang adalah $46 \%$, sedangkan pada tahun 2017 , persentase tersebut mencapai 48\% (World Bank, 2020). Hal ini menunjukkan bahwa terjadi peningkatan dalam persentase populasi pekerja part timer wanita di Jepang. Menurut Shisotsuka (1994: 108), fenomena part timer ini terjadi akibat krisis minyak yang melanda Jepang pada dekade 1970-an dan berimbas pada sistem ketenagakerjaan Jepang. Akibatnya, jumlah pekerja tidak tetap meningkat. Fenomena ini khususnya lebih cenderung terjadi pada kelompok pekerja wanita daripada kelompok pekerja laki-laki.

Selain tingkat partisipasi kerja, perlakuan terhadap pekerja laki-laki dan pekerja wanita dalam sistem ketenagakerjaan di Jepang juga terdapat perbedaan. Perbedaan perlakuan tersebut antara lain meliputi pemberian upah dan kesempatan untuk meningkatkan jenjang karir. Di Jepang, pekerja wanita diketahui mendapat upah yang lebih rendah daripada pekerja laki-laki (Sugimoto, 1997: 145; Belarmino dan Roberts, 2019: 279). Porsi upah yang diterima oleh pekerja wanita hanya sekitar $60 \%$ dari total upah yang diterima oleh pekerja laki-laki (Fukutake, 1989: 112).

Pada dasarnya, pekerja laki-laki dan pekerja wanita akan mendapatkan nominal upah yang relatif sama di masa-masa awal mereka bekerja di perusahaan-atau sekitar usia 20-an tahun-tetapi nominal upah tersebut akan mengalami perbedaan seiring dengan lamanya mereka bekerja di perusahaan tersebut (Arai dan Lechevalier, 2005: 5; Assmann, 2014: 13). Pekerja laki-laki bekerja di bawah sistem kerja seumur hidup, sedangkan pekerja wanita akan berhenti bekerja dalam kurun waktu tertentu untuk menikah dan mengurus anak (Arai dan Lechevalier, 2005: 5; Fukutake, 1989: 111; Shinotsuka, 1994: 109). Maka dari itu, ketika pekerja wanita kembali bekerja, status senioritas yang ia miliki tidak akan setinggi pekerja lakilaki, sehingga hal tersebut akan berpengaruh pada upah yang ia terima (Fukutake, 1989: 112;
Shinotsuka, 1994: 109-110). Dengan kata lain, pekerja wanita mendapatkan nominal upah yang berbeda dari pekerja laki-laki karena jangka waktu bekerja pekerja wanita tidak sepanjang jangka waktu bekerja pekerja lakilaki.

Lalu, dalam hal perekrutan dan penempatan pekerja di perusahaan, pihak managerial di perusahaan-perusahaan Jepang masih dipengaruhi oleh bias gender. Meskipun memiliki kemampuan yang sama, pekerja lakilaki cenderung lebih mudah diterima dalam proses rekrutmen perusahaan daripada pekerja wanita (Belarmino \& Roberts, 2019: 279). Hal ini karena adanya persepsi bahwa pekerja wanita memiliki kecenderungan untuk berhenti bekerja atau memiliki tingkat produktivitas yang tidak kontinyu (Arai dan Lechevalier, 2005: 6; Nemoto, 2016: 23). Karena alasan itu pula pekerja wanita cenderung ditempatkan pada posisi yang tidak memiliki jenjang karir (Assmann, 2014: 10). Dengan kata lain, kesempatan pekerja wanita untuk meningkatkan jenjang karir lebih kecil daripada pekerja lakilaki.

Selain mendapatkan perlakuan yang berbeda, pekerja wanita berisiko mengalami pelecehan seksual (Belarmino dan Roberts, 2019: 275) dan power harassment (Roberts, 2014: 27). Tidak hanya itu, pekerja wanita juga menghadapi risiko mengalami maternity harassment. Maternity harassment (matahara) mengacu pada pelecehan terhadap wanita hamil. Menurut Osakabe dalam Wulandari dan Elsy (2018: 181), salah satu bentuk matahara adalah pelecehan oleh rekan kerja yang disebabkan oleh rasa toleransi yang rendah dan rasa iri yang timbul apabila pekerja wanita yang hamil mendapatkan perlakuan khusus.

Fenomena ketidaksetaraan gender ini kemudian direfleksikan oleh media Jepang dalam bentuk penayangan serial drama. Salah satu serial drama Jepang yang merefleksikan isu gender dalam ketenagakerjaan adalah Hope: Kitai Zero no Shinnyu Shain. Oleh karena itu, pokok bahasan dalam penelitian ini berfokus pada representasi pekerja wanita dalam serial drama Hope: Kitai Zero no Shinnyu Shain. Penelitian ini bertujuan untuk mengidentifikasi dan menjelaskan bagaimana pekerja wanita direpresentasikan dalam serial drama tersebut. Diharapkan penelitian ini mampu memberikan pemahaman mengenai representasi pekerja 
wanita di Jepang yang ditayangkan oleh media, khususnya dalam serial drama.

Penelitian mengenai representasi perempuan dalam media perfilman sudah pernah dilakukan dalam bentuk penulisan artikel jurnal. Penelitian pertama yaitu Representasi Perempuan dalam Film "Star Wars VII: The Force Awaken" yang ditulis oleh Joane Priskila Kosakoy dalam Jurnal E-komunikasi vol. 4 no. 1 tahun 2016. Penelitian tersebut bertujuan untuk menjelaskan bagaimana representasi dari empat karakter wanita film Star Wars VII: The Force Awaken, yaitu Rey, Leia Organa, Maz Kanata, dan Kapten Phasma. Metode yang digunakan dalam menganalisis yaitu semiotik dengan mengacu pada kode televisi John Fiske. Hasil penelitian menunjukkan bahwa terdapat pergeseran stereotipe wanita dalam film Star Wars VII: The Force Awaken. Hal ini terlihat dari bagaimana karakter wanita dalam film tersebut mengambil peran yang umumnya dibawakan oleh karakter laki-laki, baik itu secara narasi maupun karakter.

Baik penelitian ini maupun penelitian Kosakoy (2016) menggunakan konsep representasi sebagai pokok bahasan penelitian. Namun, perbedaan kedua penelitian ini terletak pada metode yang digunakan. Penelitian ini menggunakan pendekatan semiotik Roland Barthes sebagai metode dalam menganalisis data-data, sedangkan penelitian Kosakoy menggunakan pendekatan semiotik dengan mengacu pada kode televisi John Fiske. Selain itu, unit analisis yang digunakan dalam kedua penelitian ini pun berbeda. Penelitian Kosakoy menggunakan film Star Wars VII: The Force Awaken sebagai unit analisis penelitian, sedangkan penelitian ini menggunakan serial drama Hope: Kitai Zero no Shinnyu Shain.

Penelitian kedua yang relevan dengan penelitian ini yaitu Representasi Perempuan dalam Film Cinta Suci Zahrana yang ditulis oleh Urip Mulyadi dalam Jurnal Ilmiah Komunikasi $M A K N A$ vol. 6 no. 2 tahun 2016. Penelitian ini bertujuan untuk menjelaskan bagaimana wanita direpresentasikan dalam film Cinta Suci Zahrana dan bagaimana laki-laki memegang kekuasaan dalam film tersebut. Dalam penelitiannya, Mulyadi menggunakan pendekatan semiotik untuk menggali denotasi, konotasi, dan mitos yang terkandung dalam film tersebut. Hasil penelitian menunjukkan bahwa seorang wanita akan dinilai sebagai wanita yang baik jika ia dapat mengasuh anak dan menjadi ibu rumah tangga, sehingga prestasi dan pendidikan yang tinggi bukanlah hal yang penting bagi seorang wanita. Hal inilah yang direpresentasikan oleh tokoh Zahrana dalam film Cinta Suci Zahrana.

Persamaan penelitian ini dengan penelitian Mulyadi (2016) terletak pada konsep dan metode yang digunakan. Baik penelitian Mulyadi maupun penelitian ini menggunakan konsep representasi sebagai pokok bahasan penelitian. Selain itu, kedua penelitian tersebut sama-sama menggunakan pendekatan semiotik sebagai metode analisisnya. Sementara itu, perbedaan kedua penelitian terletak pada unit analisis yang diteliti. Penelitian ini menggunakan serial drama Hope: Kitai Zero no Shinnyu Shain sebagai unit analisis, sedangkan penelitian Mulyadi menggunakan film Cinta Suci Zahrana.

Untuk mengkaji bagaimana pekerja wanita direpresentasikan dalam serial drama Hope: Kitai Zero no Shinnyu Shain, peneliti menggunakan teori gender sebagai landasan berpikir. Gender mengacu pada perbedaan psikologis, sosial, dan budaya antara laki-laki dan perempuan (Giddens, 2006: 458). Gender juga dapat diartikan sebagai ekspektasi masyarakat terhadap seorang individu agar bisa bersikap dan bertindak sesuai jenis kelaminnya (Turner, 2006: 228). Dalam hal ini, konsep gender berbeda dengan konsep jenis kelamin.

Menurut Moore dan Sinclair dalam Sunarto (1993: 110), jenis kelamin mengacu pada perbedaan biologis antara laki-laki dan perempuan yang disebabkan oleh perbedaan kromosom pada janin. Lalu, Giddens mendefinisikan jenis kelamin sebagai perbedaan anatomi dan fisiologi antara tubuh laki-laki dan perempuan (2006: 458). Dengan kata lain, jenis kelamin mengacu pada karakteristik biologis manusia, sedangkan gender dikonstruksikan secara sosioekonomi.

Karena gender dikonstruksikan secara sosioekonomi, seorang individu perlu mempelajari gender agar dapat memahami peran gendernya. Peran gender itu sendiri mengacu pada peran seorang individu yang oleh masyarakat dianggap sesuai dengan jenis kelaminnya (Sunarto, 1993: 124). Proses pembelajaran mengenai peran gender ini dapat dilakukan melalui sosialisasi gender. Dalam sosialisasi gender, seorang anak akan diajarkan 
mengenai peran gendernya dengan cara memberikan sanksi positif dan negatif (Giddens, 2006: 460). Contohnya, seorang anak laki-laki akan mendapatkan cibiran jika ia bermain boneka. Cibiran tersebut merupakan suatu bentuk sanksi negatif karena anak laki-laki itu bertindak tidak sesuai dengan peran gendernya.

Menurut Giddens (2006: 467), peran laki-laki dalam masyarakat secara umum lebih dihargai daripada perempuan. Hal ini terlihat dari peran dan tanggung jawab yang harus dipikul oleh laki-laki dan perempuan-laki-laki bertanggung jawab atas ranah publik, sedangkan perempuan bertanggung jawab atas ranah domestik. Adanya perbedaan dalam pembagian peran gender antara laki-laki dan perempuan inilah yang menyebabkan terjadinya ketidaksetaraan gender di dalam masyarakat (Giddens, 2006: 460).

Selain gender, penelitian ini juga akan dikaji menggunakan konsep representasi. Menurut Hall (2009: 17), representasi adalah memaknai suatu konsep dalam pikiran kita menggunakan bahasa. Dalam representasi terdapat dua proses-dua sistem representasiyang terlibat. Hall (2009: 17-19), menjelaskan bawah pada proses representasi yang pertama, kita akan memaknai suatu hal dengan cara menghubungkan suatu benda-seperti manusia, objek, peristiwa, maupun gagasan abstrakdengan peta konsep dalam pikiran kita. Lalu, pada proses kedua, kita akan menghubungkan peta konsep dalam pikiran kita dengan tanda atau simbol yang merepresentasikan konsep tersebut. Dalam hal ini, tanda yang dimaksud mengacu pada kata-kata, suara, atau gambar yang mengandung makna.

\section{METODE PENELITIAN}

Penelitian ini merupakan penelitian kualitatif deskriptif. Metode ini dipilih karena peneliti ingin mengkaji secara mendalam mengenai pekerja wanita yang direpresentasikan dalam serial drama Hope: Kitai Zero no Sinyuushain. Adapun analisis data dilakukan menggunakan pendekatan semiotik Roland Barthes. Pendekatan ini dipilih karena peneliti ingin menganalisis bagaimana pekerja wanita direpresentasikan dalam serial drama tersebut melalui tanda atau simbol-simbol.
Menurut Chandler (2007: 1), semiotik adalah ilmu tentang tanda. Dalam hal ini, tanda yang dimaksud tidak hanya mengacu pada 'tanda visual', tetapi juga kata-kata, gambar, suara, gestur, dan objek-segala sesuatu yang merepresentasikan hal lain (Chandler, 2007: 2). Dalam semiotik, pokok bahasan yang dikaji adalah bagaimana makna dibentuk dan bagaimana realita direpresentasikan. Menurut de Saussure dalam Hoed (2014: 15), hubungan antara tanda dan makna bersifat sosial karena didasarkan oleh konvensi sosial.

Salah satu pendekatan semiotik yang banyak digunakan dalam mengkaji tanda adalah semiotik yang dikembangkan oleh Roland Barthes. Barthes mengembangkan sistem tanda yang ada di dalam semiotik menjadi sistem konotasi. Dalam hal ini, Barthes menggunakan istilah ekspresi [E] sebagai penanda, isi [C] sebagai petanda, dan relasi [R] sebagai penghubung antara penanda dan petanda.

Menurut Barthes (1986: 89-90), sistem konotasi terbentuk atas dua sistem. Sistem pertama yaitu denotasi dan sistem kedua adalah konotasi. Sistem denotasi terdiri dari satu kesatuan ERC yang menjadi ekspresi atau penanda bagi sistem konotasi. Sistem denotasi tersebut tidak hanya terdiri dari satu sistem, tetapi juga bisa terdiri dari banyak sistem yang dikelompokkan menjadi satu kesatuan (Barthes, 1986: 91).

Adapun sumber data yang digunakan dalam penelitian ini berupa serial drama Jepang berjudul Hope: Kitai Zero no Shinnyu Shain (2016). Serial drama ini merupakan drama adaptasi dari serial drama Korea berjudul Misaeng: Incomplete Life (2014). Hope: Kitai Zero no Shinnyu Shain disutradarai oleh Kono Keita dan disiarkan di Fuji TV. Total episodenya berjumlah sembilan episode.

Serial drama Hope: Kitai Zero no Shinnyu Shain bercerita tentang Ichinose Ayumu yang bercita-cita sebagai pemain go profesional. Meskipun demikian, ia berulang kali gagal mengikuti tes untuk menjadi pemain go profesional. Kemudian, di usianya yang menginjak 23 tahun, Ichinose memutuskan untuk bekerja di sebuah perusahaan perdagangan sebagai seorang pekerja magang. Namun, karena latar belakang pendidikannya hanya sampai SMA, Ichinose kesulitan dalam beradaptasi dengan lingkungan perusahaan. 
Walaupun begitu, ia tidak menyerah dan tetap berusaha untuk bekerja dengan baik.

Data yang dijaring meliputi cuplikan adegan dan dialog dalam serial drama Hope: Kitai Zero no Shinnyu Shain. Cuplikan adegan dan dialog yang dijadikan data dalam peneltian ini berfokus pada dua karakter pegawai wanita dalam serial drama tersebut, yaitu Kazuki Akane dan Shiraishi Ryoko. Data yang dijaring dari kesembilan episode dari serial drama tersebut berjumlah 15 data.

Adapun teknik analisis yang dilakukan dalam penelitian ini meliputi identifikasi, memaknai tanda atau simbol, dan menentukan pola. Pada tahap identifikasi, peneliti akan menentukan apakah suatu cuplikan adegan mengandung simbol atau tanda yang merepresentasikan pekerja wanita atau tidak. Lalu, pada tahap pemaknaan tanda, peneliti akan menganalisis tanda yang terkandung dalam cuplikan adegan menggunakan pendekatan semiotik Roland Barthes. Terakhir, kesimpulan akan ditarik berdasarkan pola-pola yang terbentuk setelah data-data dianalisis.

\section{HASIL PENELITIAN}

Meskipun alur cerita dalam serial drama Hope: Kitai Zero no Shinnyu Shain berfokus kepada Ichinose Ayumu-seorang pekerja magang yang hanya lulusan SMA-dalam plot serial drama tersebut juga diceritakan mengenai Kazuki Akane-rekan Ichinose sesama pekerja magangdan Shiraishi Ryoko-kepala divisi produk makanan. Kedua tokoh tersebut merupakan pegawai wanita di perusahaan tempat Ichinose bekerja. Untuk mengetahui lebih lanjut mengenai representasi yang ditampilkan oleh kedua tokoh tersebut, berikut adalah hasil penelitian yang dijabarkan menggunakan pendekatan semiotik konotasi.

\section{Kelompok Data Pertama}

Data (1)

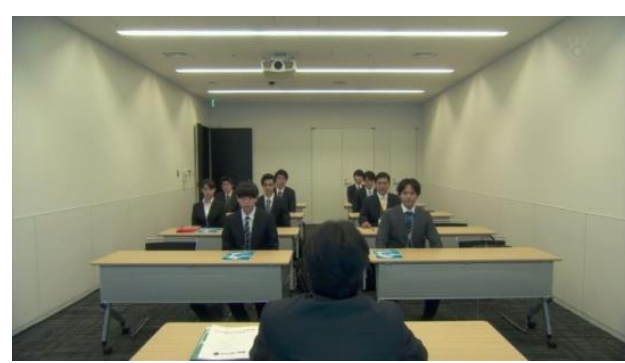

Gambar 1. Pekerja magang berkumpul untuk mengikuti orientasi.

Data (1) diambil dari episode 1 menit 05.35. Dalam adegan tersebut diceritakan bahwa para pekerja magang yang berhasil lolos tahap seleksi perekrutan perusahaan perdagangan Yoichi (Yoichi Bussan) mengikuti orientasi di hari pertama mereka magang. Pada cuplikan adegan tersebut terlihat bahwa kelompok pekerja magang didominasi oleh lakilaki. Sementara itu, pekerja magang wanita yang ada di ruangan itu hanya satu orang, yaitu Kazuki (lihat gambar 1). Dengan demikian, secara denotatif, adegan ini menunjukkan bahwa Kazuki merupakan satu-satunya calon pegawai wanita yang berhasil direkrut oleh Yoichi Bussan.

\section{Data (2)}

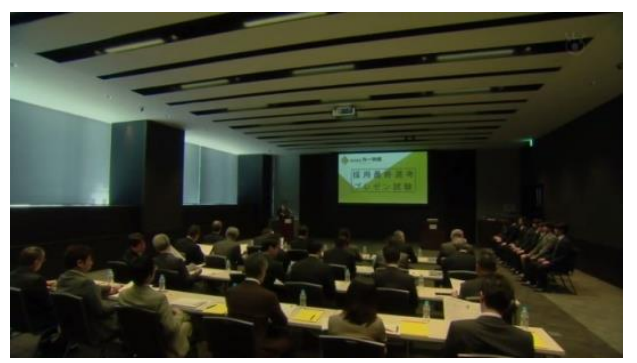

Gambar 2. Sesi presentasi oleh pekerja magang yang disaksikan oleh kepala-kepala seksi.

Data (2) diambil dari adegan dalam episode 2 menit 25.22. Adegan tersebut menceritakan tentang sesi presentasi yang diikuti oleh pekerja magang setelah mereka bekerja selama sebulan di Yoichi Bussan. Sesi presentasi tersebut merupakan seleksi tahap akhir yang harus diikuti pekerja magang agar mereka bisa menjadi pekerja tetap di Yoichi Bussan. Sesi presentasi itu disaksikan oleh kepala-kepala seksi yang bertugas menilai kecakapan masing-masing pekerja magang.

Berdasarkan gambar 2, dapat dilihat bahwa posisi kepala seksi didominasi oleh lakilaki. Hanya ada satu wanita yang duduk di 
jajaran kepala seksi, yaitu Shiraishi. Secara denotatif, hal ini menunjukkan bahwa Shiraishi merupakan satu-satunya wanita yang menjabat sebagai kepala seksi.

Baik data (1) dan data (2) menunjukkan bahwa jumlah pegawai wanita di Yoichi Bussan lebih sedikit daripada jumlah pegawai laki-laki. Bila dikaitkan dengan konteks sosial Jepang saat ini, kondisi seperti yang terjadi pada kedua data tersebut merupakan sebuah gambaran bahwa populasi wanita dalam lingkungan kerja di Jepang masih lebih rendah bila dibandingkan dengan populasi pekerja laki-laki. Menurut Belarmino dan Roberts (2019: 282), wanita memiliki peluang lebih kecil untuk diterima bekerja daripada laki-laki. Hal ini sesuai dengan gambaran dalam data (1)-Kazuki menjadi satusatunya wanita yang direkrut oleh Yoichi Bussan. Kemudian, Assman (2014: 10) juga menjelaskan bahwa partisipasi wanita Jepang dalam posisi yang lebih tinggi di dunia kerja masih lebih kecil bila dibandingkan dengan negara-negara lain. Hal ini tergambar dalam data (2)-Shiraishi menjadi satu-satunya wanita yang ada di jejeran kepala seksi.

Dengan demikian, secara denotaif, baik data (1) dan data (2) menunjukkan bahwa jumlah pegawai wanita di Yoichi Bussan lebih sedikit daripada pegawai laki-laki. Sementara itu, secara konotatif, data (1) dan data (2) menggambarkan bahwa laki-laki masih mendominasi dunia kerja di Jepang. Untuk lebih jelasnya, lihat bagan 1 .

Bagan 1. Sistem konotasi data (1) dan data (2).

\begin{tabular}{|l|l|l|l|}
\hline \multirow{5}{*}{ Konotasi } & \multicolumn{2}{|c|}{ Ekspresi } & \multicolumn{1}{c|}{ Isi } \\
\cline { 2 - 3 } & $\begin{array}{l}\text { Jumlah pegawai } \\
\text { wanita di Yoichi } \\
\text { Bussan lebih sedikit } \\
\text { daripada pekerja } \\
\text { laki-laki. }\end{array}$ & $\begin{array}{l}\text { Laki-laki } \\
\text { masih } \\
\text { mendominasi } \\
\text { ranah publik. }\end{array}$ \\
\hline \multirow{5}{*}{ Denotasi } & $\begin{array}{l}\text { Ekspresi } \\
\text { adegan } \\
\text { dalam } \\
\text { episode 1 } \\
\text { menit } \\
\text { 05.35. }\end{array}$ & $\begin{array}{l}\text { Isi } \\
\text { Pegawai } \\
\text { wang } \\
\text { direkrut } \\
\text { hanya } \\
\text { Kazuki. }\end{array}$ & \\
\hline
\end{tabular}

\begin{tabular}{|c|c|}
\hline $\begin{array}{l}\text { Cuplikan } \\
\text { adegan } \\
\text { dalam } \\
\text { episode } 1 \\
\text { menit } \\
25.22 \text {. }\end{array}$ & $\begin{array}{l}\text { Shiraishi } \\
\text { adalah } \\
\text { satu- } \\
\text { satunya } \\
\text { wanita } \\
\text { yang } \\
\text { menjadi } \\
\text { kepala } \\
\text { seksi. }\end{array}$ \\
\hline
\end{tabular}




\section{Kelompok Data Kedua}

\section{Data (3)}

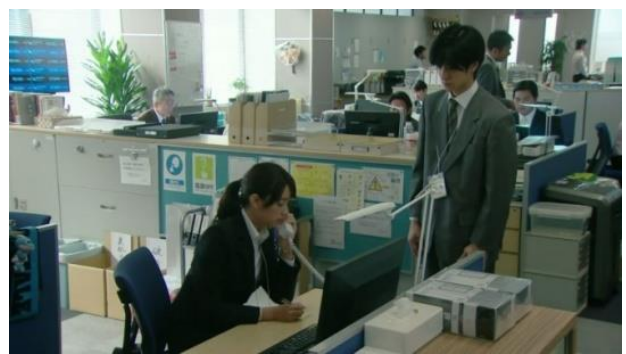

Gambar 3. Kazuki berbicara dengan klien asing melalui telepon.

Data (3) merupakan cuplikan adegan dalam episode 1 menit 12.50. Dalam adegan tersebut diceritakan bahwa Ichinose meminta bantuan Kazuki untuk menerima telepon dari klien asing. Berdasarkan gambar 3, dapat dilihat bahwa Kazuki sedang menerima telepon dari klien asing yang ditujukan kepada seksi penjualan 3-seksi tempat Ichinose ditempatkan selama masa magang. Sementara itu, Ichinose yang tidak paham dengan bahasa Inggris hanya bisa mengamati Kazuki berbicara di telepon. Dengan demikian, secara denotatif dapat dipahami bahwa Kazuki membantu Ichinose dengan kemampuan bahasa Inggrisnya.

\section{Data (4)}

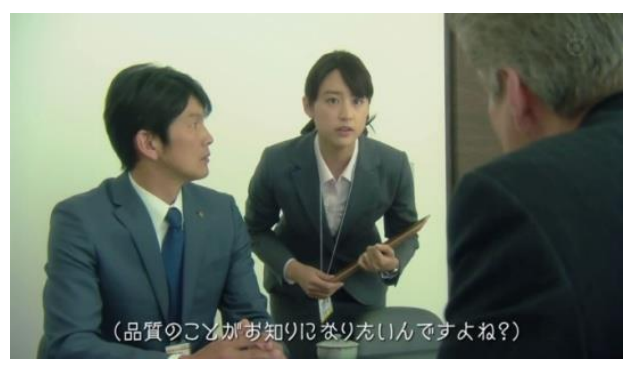

Gambar 4. Kazuki sedang mengkonfirmasi keinginan klien dengan menggunakan bahasa Rusia.

Data (4) diambil dari adegan dalam episode 1 menit 24.40. Pada adegan tersebut, terdapat kesalahpahaman dalam pertemuan bisnis antara Yuki dan kliennya yang berasal dari Rusia. Melihat Yuki yang kebingungan, Kazuki kemudian berinisiatif untuk mengkonfirmasi keinginan klien tersebut menggunakan bahasa Rusia. Maka dari itu, secara denotatif dapat dipahami bahwa Kazuki menggunakan kemapuan bahasa Rusia yang ia miliki untuk membantu Yuki yang sedang kesulitan.

Berdasarkan pemaparan denotatif pada data (3) dan data (4) dapat dilihat bahwa kedua data tersebut sama-sama memperlihatkan kemampuan Kazuki dalam berbahasa asing. Oleh karena itu, secara denotatif, kedua data tersebut menunjukkan bahwa Kazuki membantu Yuki dan Ichinose dengan memanfaatkan kemampuan bahasa asing yang ia kuasai. Lalu, bila mengacu pada konteks sosial yang terjadi pada dunia kerja di Jepang, maka apa yang dilakukan oleh Kazuki tersebut merupakan sebuah bentuk dukungan terhadap pihak laki-laki. Belarmino dan Roberts (2019: 277) menyatakan bahwa wanita berperan dalam mendukung dan membantu laki-laki. Maka dari itu, meskipun seorang wanita memiliki keahlian tertentu, keahlian tersebut digunakan untuk membantu laki-laki. Hal ini lah yang direpresentasikan dalam data (3) dan data (4).

Dengan demikian, sistem denotasi dari kedua data tersebut menunjukkan bahwa Kazuki memanfaatkan kemampuan bahasa asingnya untuk membantu Ichinose dan Yuki. Sementara itu, sistem konotasi data (3) dan data (4) menunjukkan bahwa meskipun memiliki keahlian tertentu, wanita akan diposisikan sebagai pihak yang membantu laki-laki.Untuk lebih jelasnya, lihat bagan 2 . 
Bagan 2. Sistem konotasi data (3) dan data (4).

\begin{tabular}{|c|c|c|c|}
\hline \multirow[b]{2}{*}{$\begin{array}{c}\text { Konotas } \\
\text { i }\end{array}$} & \multicolumn{2}{|c|}{ Ekspresi } & Isi \\
\hline & \multicolumn{2}{|c|}{$\begin{array}{l}\text { Dengan kemampuan } \\
\text { bahasa asingnya, Kazuki } \\
\text { berusaha membantu } \\
\text { Ichinose dan Yuki. }\end{array}$} & $\begin{array}{l}\text { Meskipun } \\
\text { memiliki } \\
\text { keahlian } \\
\text { tertentu, } \\
\text { wanita } \\
\text { akan } \\
\text { diposisika } \\
\text { n sebagai } \\
\text { pihak } \\
\text { yang } \\
\text { membantu } \\
\text { laki-laki. }\end{array}$ \\
\hline \multirow{3}{*}{$\begin{array}{c}\text { Denotas } \\
\text { i }\end{array}$} & Ekspresi & Isi & \\
\hline & $\begin{array}{l}\text { Cuplika } \\
\mathrm{n} \\
\text { adegan } \\
\text { dalam } \\
\text { episode } \\
1 \text { menit } \\
12.50 .\end{array}$ & $\begin{array}{l}\text { Kazuki } \\
\text { membantu } \\
\text { Ichinose } \\
\text { dengan } \\
\text { menggunaka } \\
\mathrm{n} \\
\text { kemampuan } \\
\text { bahasa } \\
\text { Inggrisnya. }\end{array}$ & \\
\hline & $\begin{array}{l}\text { Cuplika } \\
\mathrm{n} \\
\text { adegan } \\
\text { dalam } \\
\text { episode } \\
1 \text { menit } \\
24.40 .\end{array}$ & $\begin{array}{l}\text { Kazuki } \\
\text { membantu } \\
\text { Yuki dengan } \\
\text { menggunaka } \\
\text { n } \\
\text { kemampuan } \\
\text { bahasa } \\
\text { Rusianya. }\end{array}$ & \\
\hline
\end{tabular}

\section{Kelompok Data Ketiga}

\section{Data (5)}

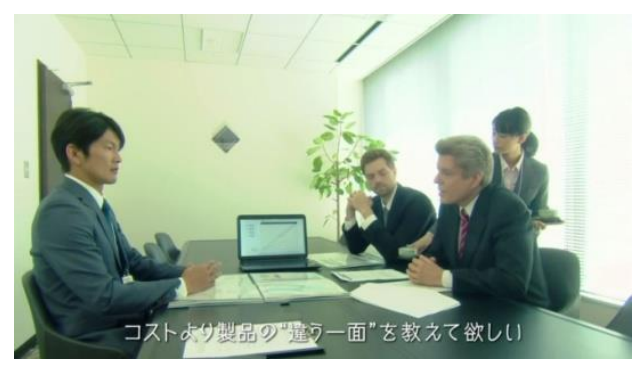

Gambar 5. Kazuki menyuguhkan minuman.

Data (5) diambil dari adegan dalam episode 1 menit 24.23. Dalam adegan tersebut terlihat Yuki sedang mengadakan pertemuan bisnis dengan dua orang klien asing. Sementara itu, Kazuki berdiri di sisi klien dan meletakkan secangkir minuman (lihat gambar 5). Secara denotatif, hal ini menunjukkan bahwa Kazuki sedang bertugas menyuguhkan minuman kepada ketiga orang tersebut.

\section{Data (6)}

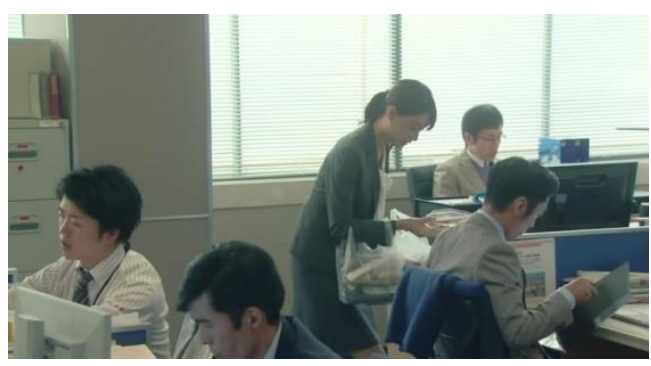

Gambar 6. Kazuki membagikan makan siang.

Data (6) diambil dari adegan dalam episode 3 menit ke-5. Dalam adegan tersebut diceritakan Kazuki sedang membagikan makan siang kepada rekan-rekan satu divisinya. Berdasarkan gambar 6, dapat dilihat bahwa Kazuki mengeluarkan sekotak makanan dari kantong plastik dan meletakkannya di samping Hiyama. Hal ini menunjukkan bahwa secara denotatif, Kazuki sedang menyajikan makan siang kepada rekan kerjanya.

\section{Data (7)}

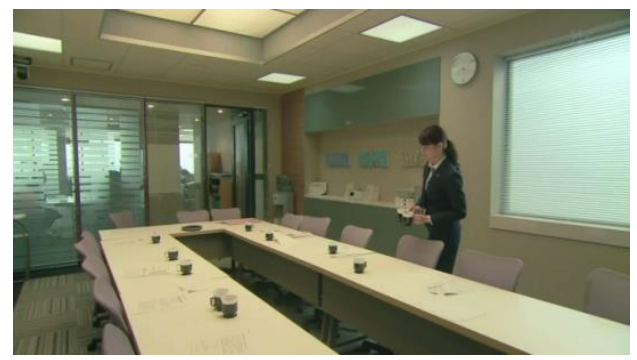

Gambar 7. Kazuki membereskan ruang rapat yang berantakan.

Data (7) diambil dari adegan dalam episode 3 menit 27.36. Dalam adegan tersebut diceritakan bahwa atasan Kazuki baru saja menyelesaikan rapat dan menyuruh Kazuki untuk membereskan ruang rapat. Dengan patuh, Kazuki segera pergi ke ruang rapat dan membereskannya. Berdasarkan gambar 7, dapat dilihat bahwa ruang rapat tersebut berantakanterdapat gelas-gelas kosong dan kertas-kertas di atas meja. Kazuki mengambil gelas-gelas tersebut dan mengumpulkannya untuk dibuang. Hal ini secara denotatif menunjukkan bahwa 
Kazuki sedang membereskan ruang rapat yang berantakan.

Berdasarkan data (5), data (6), dan data (7), dapat diketahui bahwa Kazuki mengerjakan pekerjaan kasar seperti menyuguhkan minuman, menyajikan makanan, dan membereskan ruang rapat. Bila mengacu pada konteks sosial di Jepang, fenomena pekerja wanita yang mengejakan tugas-tugas layaknya pelayan tersebut cukup lumrah ditemukan. Hal ini karena pekerja wanita dianggap sebagai "office flowers" yang dituntut untuk mengerjakan pekerjaan kasar, salah satunya membuat teh untuk rekan kerjanya (Barret, 2004: 5; Villa, 2019: 70).

Maka dari itu, sistem denotasi pada data (5), data (6), dan data (7) menunjukkan bahwa Kazuki bertugas mengerjakan pekerjaan kasar. Lalu, bila dihubungkan dengan konteks sosial Jepang saat ini, maka sistem konotasi yang terbentuk menunjukkan bahwa pekerja wanita di Jepang dituntut untuk mengerjakan pekerjaan kasar. Untuk lebih jelasnya, lihat bagan 3.
Bagan 3. Sistem konotasi data (5), data (6), dan data (7).

\begin{tabular}{|c|c|c|c|}
\hline \multirow[b]{2}{*}{ Konotasi } & \multicolumn{2}{|c|}{ Ekspresi } & Isi \\
\hline & \multicolumn{2}{|c|}{$\begin{array}{l}\text { Kazuki bertugas } \\
\text { mengerjakan pekerjaan } \\
\text { kasar. }\end{array}$} & $\begin{array}{l}\text { Pekerja } \\
\text { wanita } \\
\text { dituntut } \\
\text { untuk } \\
\text { mengerjakan } \\
\text { pekerjaan } \\
\text { kasar. }\end{array}$ \\
\hline \multirow{4}{*}{ Denotasi } & Ekspresi & Isi & \\
\hline & $\begin{array}{l}\text { Cuplikan } \\
\text { adegan } \\
\text { dalam } \\
\text { episode } \\
1 \text { menit } \\
24.23 \text {. }\end{array}$ & $\begin{array}{l}\text { Kazuki } \\
\text { menyajikan } \\
\text { teh kepada } \\
\text { Yuki dan } \\
\text { klien asing }\end{array}$ & \\
\hline & $\begin{array}{l}\text { Cuplikan } \\
\text { adegan } \\
\text { dalam } \\
\text { episode } \\
3 \text { menit } \\
05.00 .\end{array}$ & $\begin{array}{l}\text { Kazuki } \\
\text { menyajikan } \\
\text { makan siang } \\
\text { untuk rekan } \\
\text { kerjanya. }\end{array}$ & \\
\hline & $\begin{array}{l}\text { Cuplikan } \\
\text { adegan } \\
\text { dalam } \\
\text { episode } \\
3 \text { menit } \\
27.36 .\end{array}$ & $\begin{array}{l}\text { Kazuki } \\
\text { membereskan } \\
\text { ruang rapat } \\
\text { yang } \\
\text { berantakan. }\end{array}$ & \\
\hline
\end{tabular}

\section{Kelompok Data Keempat}

\section{Data (8)}

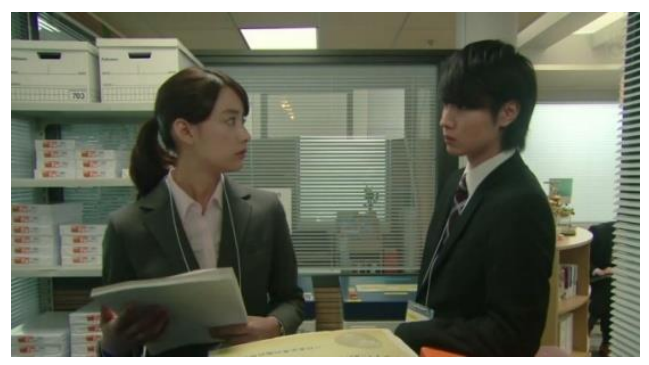

Gambar 8. Niimura mengajak Kazuki untuk menjadi rekan satu timnya dalam sesi presentasi.

Data (8) diambil dari adegan dalam episode 2 menit 10.35. Dalam adegan itu terjadi percakapan antara Kazuki dan Niimura. Kedua tokoh tersebut membicarakan tentang partner 
untuk sesi presentasi di akhir masa magang. Berikut cuplikan dialog tersebut.

$\begin{array}{ll}\text { Niimura } & \begin{array}{l}\text { : Asal kau tahu saja, kau } \\ \text { tidak akan mendapatkan } \\ \text { partner selain aku. }\end{array} \\ \text { Kazuki } & : \text { Kenapa? } \\ \text { Niimura } & \begin{array}{l}\text { Karena kau terlalu } \\ \text { hebat. Mereka takut } \\ \end{array} \\ & \text { mereka akan kalah } \\ & \text { mencolok darimu jika } \\ & \text { berpasangan denganmu. }\end{array}$

Kazuki : Tidak mungkin....

Dalam percakapan tersebut, Niimura menyebutkan bahwa Kazuki adalah wanita yang hebat. Meskipun begitu, kehebatan yang dimiliki Kazuki justru membuat pekerja magang lain-yang notabene merupakan laki-lakienggan untuk menjadi rekan satu timnya. Maka dari itu, secara denotatif, data (8) menunjukkan bahwa sosok Kazuki yang hebat membuat rekan-rekannya sesama pekerja magang merasa risi.

Menurut Poerwandari dkk. (2014: 110), meskipun kuat dan cerdas, seorang wanita harus memiliki sifat yang lemah lembut agar laki-laki tidak merasa rendah diri dan tersaingi. Hal ini karena adanya stigma bahwa laki-laki memiliki kedudukan yang lebih tinggi daripada wanita. Oleh karena itu, apabila ada wanita yang lebih hebat daripada laki-laki, maka laki-laki tersebut akan merasa posisinya sebagai pihak yang lebih superior akan terenggut. Kondisi inilah yang kemudian digambarkan dalam data (8).

Dengan begitu, secara denotatif, data (8) menunjukkan bahwa kehebatan Kazuki membuat rekannya sesama pekerja magang merasa risi. Sementara itu, secara konotatif, data (8) merepresentasikan fenomena bahwa wanita yang memiliki superioritas yang lebih tinggi daripada laki-laki tidak akan disukai. Untuk lebih jelasnya, lihat bagan 4 .
Bagan 4. Sistem konotasi data (8).

\begin{tabular}{|c|c|c|c|}
\hline \multirow[b]{2}{*}{ Konotasi } & \multicolumn{2}{|c|}{ Ekspresi } & Isi \\
\hline & \multicolumn{2}{|c|}{$\begin{array}{l}\text { Kehebatan Kazuki } \\
\text { membuat rekan- } \\
\text { rekannya sesama } \\
\text { pekerja magang merasa } \\
\text { risi. }\end{array}$} & $\begin{array}{l}\text { Wanita } \\
\text { yang } \\
\text { terlalu } \\
\text { hebat atau } \\
\text { superior } \\
\text { tidak akan } \\
\text { disukai }\end{array}$ \\
\hline \multirow[b]{2}{*}{ Denotasi } & Ekspresi & Isi & \\
\hline & $\begin{array}{l}\text { Cuplikan } \\
\text { dialog } \\
\text { antara } \\
\text { Kazuki } \\
\text { dan } \\
\text { Niimura } \\
\text { dalam } \\
\text { episode } \\
2 \text { menit } \\
10.35 .\end{array}$ & $\begin{array}{l}\text { Kazuki } \\
\text { dianggap } \\
\text { terlalu } \\
\text { hebat } \\
\text { sehingga } \\
\text { tidak ada } \\
\text { yang mau } \\
\text { satu tim } \\
\text { dengannya } \\
\text { dalam sesi } \\
\text { presentasi. }\end{array}$ & \\
\hline
\end{tabular}

\section{Kelompok Data Kelima}

\section{Data (9)}

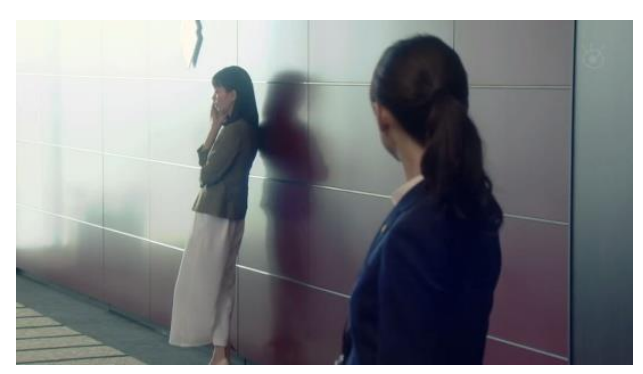

Gambar 9. Kazuki melihat Shiraishi sedang berdebat dengan suaminya melalui telepon.

Data (9) diambil dari adegan dalam episode 3 menit 31.05. Adegan tersebut memperlihatkan Kazuki secara tidak sengaja mendengar Shiraishi yang sedang berbicara dengan suaminya melalui sambungan telepon. Shiraishi diminta oleh suaminya untuk menjemput anak mereka. Meskipun sedikit enggan, Shiraishi berusaha untuk menyanggupinya. Untuk lebih jelasnya, berikut cuplikan pembicaraan Shiraishi di telepon.

Shiraishi : Sudah kubilang, aku tidak bisa. Sudah kubilang di awal kalau minggu ini aku sibuk. 
Jika kau memberitahuku secara mendadak, aku tidak bisa menyanggupinya. Jika urusanmu sampai pukul tujuh, aku bisa meminta untuk memperpanjang waktu di tempat penitipan anak, jadi lakukanlah sesuatu. Baiklah. Aku akan mengatur waktu.

Berdasarkan cuplikan pembicaraan tersebut dapat diketahui bahwa suami Shiraishi meminta Shiraishi untuk menjemput anak mereka. Namun, Shiraishi tidak bisa melakukannya karena ada sibuk. Meskipun demikian, pada akhirnya Shiraishi memutuskan untuk mengambil alih tanggung jawab suaminya untuk menjemput anak dan mengubah jadwalnya. Dengan demikian, secara denotatif data (9) menunjukkan bahwa suami Shiraishi melemparkan tanggung jawab kepada Shiraishi, sehingga Shiraishi terpaksa harus mengorbankan waktu bekerja demi anaknya.

\section{Data (10)}

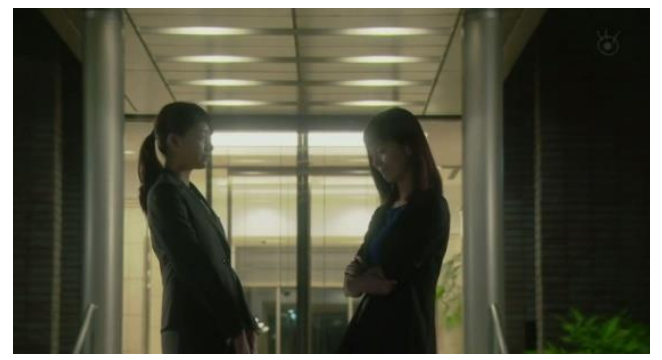

Gambar 10. Kazuki dan Shiraishi berbincangbincang.

Data (10) diambil dari adegan dalam episode 4 menit 36.39. Adegan tersebut menceritakan Shiraishi yang berterima kasih kepada Kazuki karena telah membantu menjemput anaknya dari tempat penitipan anak. Pembicaraan tersebut kemudian berlanjut pada pengalaman Shiraishi dalam menjalankan perannya sebagai ibu sekaligus berkarir di tempat kerja. Berikut cuplikan dialog antara kedua tokoh tersebut.

$\begin{array}{ll}\text { Shiraishi } & \text { Maafkan aku karena } \\ & \text { telah melibatkanmu } \\ \text { dalam urusan pribadiku. }\end{array}$

Kazuki : Tidak apa-apa.

\begin{abstract}
Shiraishi : Aku dan suami akan saling mengonfirmasi jadwal masing-masing dan memutuskan siapa yang akan pergi menjemput, tapi selalu saja seperti ini. Meskipun dia tidak pernah mengatakannya, dia selalu berpikir bahwa karena aku wanita maka aku lebih mudah untuk pulang ke rumah. Meskipun kami adalah suami istri, rasanya justru seperti berbicara dengan orang asing. Sulit sekali.
\end{abstract}

Kazuki : Entah mengapa itu sedikit tidak terduga.

Shiraishi : Apa maksudnya tidak terduga?

Kazuki : Aku selalu berpikir bahwa $\mathrm{Bu}$ Kadiv Shiraishi selalu sempurna dalam hal apapun.

Shiraishi : Tentu saja tidak seperti itu. Saat ini aku sudah kewalahan dengan apa yang ada di depan mataku. Aku tidak bisa bersantai. Saat aku memutuskan untuk memiliki anak, aku memutuskan untuk tetap bekerja karena aku menyukai pekerjaan ini dan aku ingin terus mengembangkan diri. Tentu saja, meskipun saat ini aku sibuk, aku tidak menyesalinya. Tetapi, terkadang aku tidak yakin. Aku terlalu mementingkan

pekerjaanku, pasti aku sudah membuat anakku sedih.

Berdasarkan dialog tersebut dapat diketahui bahwa Shiraishi memutuskan untuk 
tetap bekerja meskipun sudah memiliki anak. Keputusannya tersebut kemudian membuatnya terjebak dalam keraguan. Di satu sisi, ia tidak menyesal telah melanjutkan karirnya, sedangkan di sisi lain ia justru menyesal karena terlalu mementingkan pekerjaan sehingga membuat anaknya sedih. Dengan demikian, secara denotatif, dialog tersebut menunjukkan bahwa meskipun sulit, Shiraishi memutuskan untuk tetap bekerja sekaligus mengurus keluarga.

Bila melihat pola yang terbentuk dari data (9) dan data (10), dapat diketahui bahwa sistem denotasi yang terbentuk dari kedua data tersebut menunjukkan bahwa Shiraishi harus berjuang dalam karirnya sekaligus mengurus anak. Hal ini merepresentasikan fenomena yang terjadi pada pekerja wanita di Jepang. Menurut Poerwandari dkk. (2014: 111), ketika seorang wanita bekerja di luar rumah, mereka harus berjuang dalam menjalankan tugas-tugas domestik tanpa dukungan yang memadai dari pasangannya. Dengan begitu, dapat dikatakan bahwa sistem konotasi yang terbentuk dari data (9) dan (10) ialah bahwa pekerja wanita harus berjuang dalam ranah publik sekaligus domestik tanpa mendapatkan bantuan yang cukup dari pasangannya. Untuk lebih jelasnya, lihat bagan 5.
Bagan 5. Sistem konotasi data (9) dan data (10).

\begin{tabular}{|c|c|c|c|}
\hline \multirow[b]{2}{*}{$\begin{array}{c}\text { Konotas } \\
\mathbf{i}\end{array}$} & \multicolumn{2}{|c|}{ Ekspresi } & Isi \\
\hline & \multicolumn{2}{|c|}{$\begin{array}{l}\text { Shiraishi harus berjuang } \\
\text { dalam karirnya sekaligus } \\
\text { mengurus anak tanpa } \\
\text { mendapatkan bantuan } \\
\text { yang memadai dari } \\
\text { suaminya. }\end{array}$} & $\begin{array}{l}\text { Pekerja } \\
\text { wanita } \\
\text { harus } \\
\text { berjuang } \\
\text { dalam } \\
\text { ranah } \\
\text { publik } \\
\text { sekaligus } \\
\text { domestik } \\
\text { tanpa } \\
\text { bantuan } \\
\text { yang } \\
\text { cukup } \\
\text { dari } \\
\text { pasangan }\end{array}$ \\
\hline \multirow{3}{*}{$\begin{array}{c}\text { Denotas } \\
\text { i }\end{array}$} & Ekspresi & Isi & \\
\hline & $\begin{array}{l}\text { Cuplika } \\
\mathrm{n} \text { dialog } \\
\text { dalam } \\
\text { episode } \\
4 \text { menit } \\
21.18 .\end{array}$ & $\begin{array}{l}\text { Suami } \\
\text { Shiraishi } \\
\text { melemparkan } \\
\text { tanggung } \\
\text { jawab kepada } \\
\text { Shiraishi, } \\
\text { sehingga } \\
\text { Shiraishi } \\
\text { terpaksa } \\
\text { mengorbanka } \\
\text { n waktu } \\
\text { bekerja demi } \\
\text { anaknya. }\end{array}$ & \\
\hline & $\begin{array}{l}\text { Cuplika } \\
\mathrm{n} \text { dialog } \\
\text { dalam } \\
\text { episode } \\
4 \text { menit } \\
36.39 .\end{array}$ & $\begin{array}{l}\text { Meskipun } \\
\text { sulit, Shiraishi } \\
\text { memustuskan } \\
\text { untuk tetap } \\
\text { bekerja } \\
\text { sekaligus } \\
\text { mengurus } \\
\text { keluarga. }\end{array}$ & \\
\hline
\end{tabular}




\section{Kelompok Data Keenam}

\section{Data (11)}

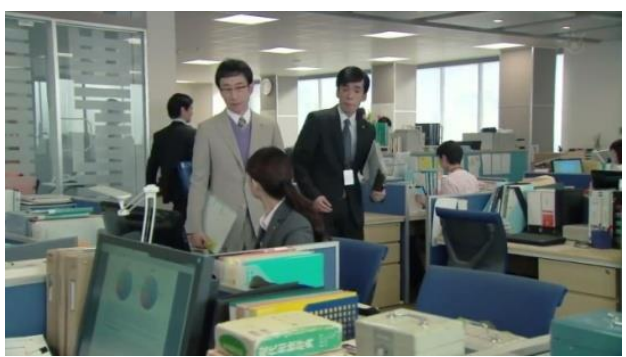

Gambar 11. Terasaka berprasangka buruk terhadap Kazuki mengenai alasannya keluar dari pekerjaan sebelumnya.

Data (11) diambil dari episode 7 menit 12.02. Dalam episode terdapat pembicaraan antara Terasaka, Kazuki, dan Toguchi mengenai alasan Kazuki mengundurkan diri dari perusahaan Futabi. Berikut cuplikan percakapan antara ketiga tokoh tersebut.

$\begin{array}{ll}\text { Terasaka } & \text { : Kazuki. Dulu kau } \\ & \text { adalah bawahannya } \\ & \text { Takase-san, bukan? }\end{array}$

$\begin{array}{ll}\text { Kazuki } & \text { : Benar. } \\ \text { Terasaka } & \text { : Mengapa kau keluar } \\ & \text { dari Futabi? }\end{array}$

$\begin{array}{ll}\text { Kazuki } & : \ldots . \\ \text { Terasaka } & : \quad \text { Sudah kuduga. } \\ & \text { Firasatku tepat. }\end{array}$

Toguchi : Apa maksudnya?

Terasaka : Kau ini benar-benar lamban. Dia menggunakan pesonanya sebagai wanita. Aku yakin kau pasti juga menggoda Hiyama. Pantas saja sikap Hiyama tiba-tiba berubah.

Kazuki : Tolong tarik kembali ucapanmu!

Terasaka : Hah? Apa-apaan sikapmu itu di depan atasanmu! Berani sekali kau berbicara seperti itu!
Dalam percakapan di atas, Terasaka mengutarakan prasangkanya bahwa alasan penyebab dari perubahan sikap Hiyama terhadap Kazuki adalah karena Kazuki telah menggodanya. Menurutnya, hal tersebut berkaitan dengan alasan pengunduran diri Kazuki dari Futabi. Dengan demikian, sistem denotasi yang terkandung dalam cuplikan percakapan tersebut adalah Kazuki dituduh sebagai seorang penggoda laki-laki.

\section{Data (12)}

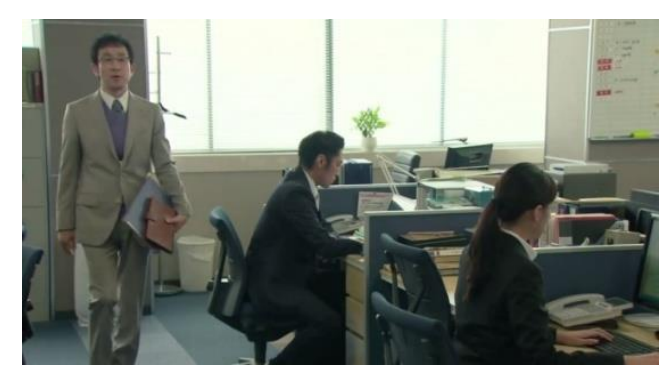

Gambar 12. Terasaka memberikan instruksi kepada Kazuki sambil berlalu.

Data (12) diambil dari adegan dalam episode 8 menit 31.20. Dalam adegan tersebut, Terasaka meminta Kazuki untuk menyiapkan perjamuan makan. Selain itu, Terasaka juga memberikan instruksi kepada Kazuki mengenai apa yang harus ia lakukan dalam perjamuan itu. Berikut cuplikan dialog antara Terasaka dan Kazuki dalam adegan tersebut.

Terasaka : Kazuki, apakah kau sudah memesan tempat untuk perjamuan besok?

Kazuki : Sudah.

Terasaka : Besok pakailah rok pendek saat kau datang. Keahlianmu adalah menggoda laki-laki, bukan? Duduklah di sebelah direktur dan layani dia. Mengerti?

Dalam dialog tersebut, Terasaka memberi instruksi kepada Kazuki untuk mengenakan rok pendek. Selain itu, ia juga menyuruh Kazuki untuk duduk di sebelah direktur dan melayaninya saat perjamuan berlangsung. Terasaka memberikan instruksiinstruksi tersebut karena ia beranggapan bahwa Kazuki pandai dalam menggoda laki-laki. Oleh karena itu, secara denotatif, dialog tersebut 
menunjukkan bahwa Kazuki harus melayani dan menggoda direktur.

Berdasarkan pola yang terbentuk dari data (11) dan data (12), dapat diketahui bahwa Kazuki mengalami sekuhara (sexual harassment) yang dilakukan oleh Terasaka-atasannya. Sekuhara merupakan merupakan tidakan seksual, baik verbal maupun tingkah laku, yang dilakukan kepada pekerja wanita tanpa sepersetujuan mereka sehingga menyebabkan "kerugian dalam kinerja bisnis" dan "kemunduran di lingkungan kerja" (Sugimoto, 1997: 157). Ucapan dan tingkah laku yang dimaksud mengacu pada pembicaraan seksual, sentuhan fisik, tindakan mempertontonkan halhal terkait pornografi, rayuan, dan bahkan pemerkosaan atau usaha pemerkosaan (Huen, 2007: 814). Dengan kata lain, tuduhan bahwa Kazuki menggoda laki-laki dan instruksi untuk melayani dan menggoda direktur yang dilakukan oleh Terasaka termasuk ke dalam sekuhara.

Di Jepang, kasus sekuhara merupakan isu yang relatif baru di kalangan masyarakat. Sebelum EEOL (Equal Employment Opportunity Law) diamandemen pada tahun 1997, sekuhara tidak dianggap sebagai sebuah masalah sosial (Huen, 2007: 812). Meskipun demikian, kasuskasus sekuhara sudah lebih lama ada di kalangan masyarakat Jepang, khususnya di lingkungan kerja. Namun, isu mengenai kasus sekuhara masih dianggap sebagai masalah pribadi antara individu yang satu dengan indvidu yang lain, sehingga hukum mengenai sekuhara belum dibentuk sampai akhir dekade 1990-an (Huen, 2007: 812).

Kasus sekuhara yang ditangani oleh Pengadilan Distrik Fukuoka pada tahun 1992 menjadi kasus sekuhara pertama yang muncul di permukaan. Berkat kasus itulah praktik sekuhara di lingkungan kerja kemudian terungkap (Huen, 2007: 812). Hukum mengenai isu sekuhara pun dibentuk sebagai bagian dari EEOL. Selain itu, pemerintah Jepang juga membuat panduan untuk perusahaan-perusahaan mengenai cakupan definisi sekuhara dan prosedur terkait sekuhara. Hal ini dilakukan sebagai usaha dalam menanggulangi kasus tersebut di tempat kerja (Huen, 2007: 812).

Dengan demikian, sistem denotasi dari data (11) dan data (12) menunjukkan bahwa Kazuki mengalami sekuhara yang dilakukan oleh atasannya. Lalu, bila sistem denotasi tersebut dikaitkan dengan fenomena sekuhara yang terjadi di kalangan masyarakat Jepang, maka sistem konotasi dari kedua data tersebut menunjukkan bahwa kasus sekuhara dapat menimpa wanita di tempat kerja. Untuk lebih jelasnya, lihat bagan 6 .

Bagan 6. Sistem konotasi data (11) dan data (12).

\begin{tabular}{|c|c|c|c|}
\hline & \multicolumn{2}{|c|}{ Ekspresi } & Isi \\
\hline Konotasi & \multicolumn{2}{|c|}{$\begin{array}{l}\text { Kazuki mengalami } \\
\text { sekuhara yang } \\
\text { dilakukan oleh } \\
\text { atasannya. }\end{array}$} & $\begin{array}{l}\text { Kasus } \\
\text { sekuhara } \\
\text { dapat } \\
\text { menimpa } \\
\text { wanita di } \\
\text { tempat } \\
\text { kerja. }\end{array}$ \\
\hline \multirow{3}{*}{ Denotasi } & Ekspresi & Isi & \\
\hline & $\begin{array}{l}\text { Cuplikan } \\
\text { dialog } \\
\text { dalam } \\
\text { episode } 7 \\
\text { menit } \\
12.02 .\end{array}$ & $\begin{array}{l}\text { Kazuki } \\
\text { dituduh } \\
\text { sebagai } \\
\text { seorang } \\
\text { penggoda } \\
\text { laki-laki. }\end{array}$ & \\
\hline & $\begin{array}{l}\text { Cuplikan } \\
\text { dialog } \\
\text { dalam } \\
\text { episode } 8 \\
\text { menit } \\
31.20 \text {. }\end{array}$ & $\begin{array}{l}\text { Kazuki } \\
\text { diberi } \\
\text { instruksi } \\
\text { untuk } \\
\text { melayani } \\
\text { dan } \\
\text { menggoda } \\
\text { direktur. }\end{array}$ & \\
\hline
\end{tabular}

\section{Kelompok Data Ketujuh}

\section{Data (13)}

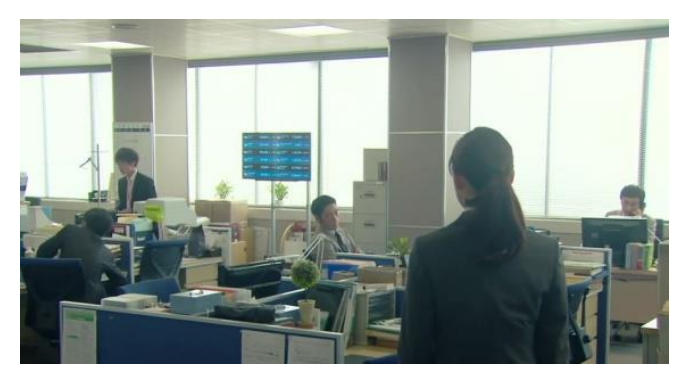

Gambar 13. Kazuki diabaikan saat mengucapkan salam. 
Data (13) diambil dari adegan dalam episode 3 menit 43.42. Dalam adegan tersebut diceritakan bahwa saat Kazuki datang ke perusahaan dan mengucapkan salam kepada rekan-rekan satu divisinya, tidak ada satu pun dari mereka yang membalas salam Kazuki. Hal ini dapat dilihat dari bagaimana rekan-rekan kerjanya tersebut berpura-pura tidak mendengar dan justru sibuk dengan urusannya masingmasing (lihat gambar 13). Maka dari itu, sistem denotasi pada data (13) menunjukkan bahwa Kazuki menerima pengabaian dari rekan kerjanya.

\section{Data (14)}

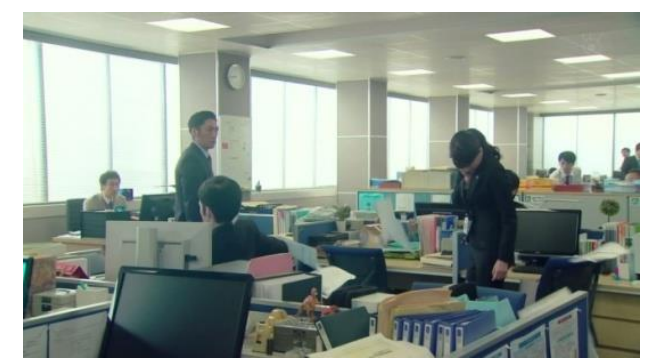

Gambar 14. Hiyama melempar kertas laporan ke arah Kazuki.

Data (14) diambil dari adegan dalam episode 4 menit 03.09. Adegan ini menceritakan kemarahan Hiyama karena format penulisan laporan yang dibuat oleh Kazuki tidak sesuai dengan ketentuan. Meskipun begitu, Kazuki berusaha membela diri dengan mengatakan bahwa ketentuan format penulisan yang ada sudah kuno, sehingga ia memutuskan untuk sedikit memodifikasinya. Alhasil, Hiyama semakin dibuat marah dan menuduh Kazuki membenci divisinya. Tidak hanya itu, Hiyama juga melemparkan kertas laporan tersebut ke arah Kazuki hingga membuat Kazuki terluka (lihat gambar 14). Oleh karena itu, secara denotatif, data (14) menunjukkan bahwa Hiyama melempar kertas laporan ke arah Kazuki.

\section{Data (15)}

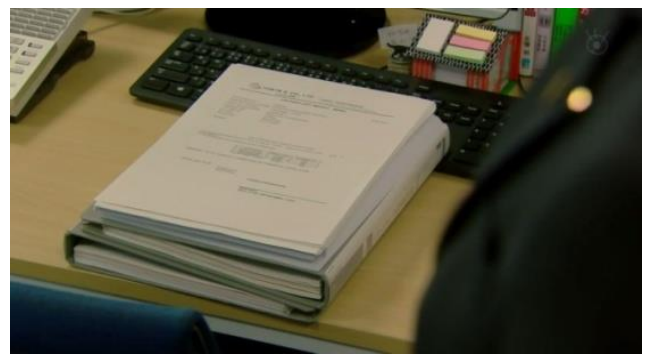

Gambar 15. Tumpukan pekerjaan baru untuk Kazuki.

Data (15) diambil dari adegan dalam episode 4 menit 12.22. Dalam adegan tersebut diceritakan bahwa tepat saat Kazuki hendak pulang setelah melakukan OJT (on the job training), ia diminta kembali ke kantor oleh Hiyama. Setelah ia sampai di ruangan, betapa terkejutnya dia saat Hiyama memberikan instruksi soal pekerjaan yang harus ia selesaikan. Untuk lebih jelasnya, berikut cuplikan dialog antara kedua tokoh tersebut.

Hiyama : Tolong cek daftar pengepakan. Jika tidak ada masalah, segera kirimkan ke perusahaan pengiriman. Daftarnya ada di situ.

\begin{tabular}{|c|c|}
\hline Kazuki & $\therefore \ldots$ \\
\hline Hiyama & $\begin{array}{l}\text { : Ada apa? Kau merasa } \\
\text { keberatan lagi? }\end{array}$ \\
\hline Kazuki & : Tidak. \\
\hline Hiyama & $\begin{array}{l}\text { Kau tidak akan } \\
\text { beralasan bahwa kau } \\
\text { saat ini sedang OJT } \\
\text { sehingga kau tidak perlu } \\
\text { mengerjakan pekerjaan } \\
\text { di sini, bukan? }\end{array}$ \\
\hline
\end{tabular}

Kazuki : Tidak.

Dari dialog tersebut dapat diketahui bahwa meskipun Kazuki sedang menjalani OJT, Hiyama tetap memberikan pekerjaan kepadanya. Terlebih lagi, pekerjaan yang diberikan tersebut cukup banyak (lihat gambar 15). Maka dari itu, adegan ini secara denotatif menunjukkan bahwa Kazuki diberikan pekerjaan baru tepat sebelum pulang.

Bila melihat pola yang terbentuk antara data (13), data (14), dan data (15), dapat 
diketahui bahwa Kazuki mengalami pawahara (power harassment) di tempat kerjanya. Menurut Hsiao (2015: 194), pawahara mengacu pada perlakuan yang merugikan yang terjadi di tempat kerja. Pawahara terdiri dari enam kategori, yaitu 1) menyerang secara fisik; 2) menyerang secara emosional; 3) mengisolasi individu secara sosial; 4) menugaskan pekerjaan terlalu berlebihan; 5) menyuruh dengan tujuan merendahkan; 6) mencampuri kehidupan pribadi (Kementerian Kesehatan, Ketenagakerjaan, dan Kesejahteraan dalam Hsio, 2015: 186-187).

Berdasarkan denotasi yang terdapat dalam data (13), data (14), dan data (15), pawahara yang dialami oleh Kazuki masingmasingmasuk ke dalam tiga kategori. Pertama, data (13) masuk dalam kategori pawahara ketiga, yaitu mengisolasi individu secara sosial. Menurut Kementerian Kesehatan, Ketenagakerjaan, dan Kesejahteraan dalam Hsio, (2015: 186) salah satu kasus yang termasuk dalam kategori tersebut yaitu melakukan pengabaian saat mengucapkan salam, bahkan atasan enggan untuk berbicara dengannya. Hal ini terepresentasikan dalam data (13) yang menunjukkan bahawa Kazuki diabaikan oleh rekan-rekan satu divisinya.

Kedua, data (14) masuk dalam kategori pawahara kedua, yaitu menyerang secara emosional. Salah satu kasus yang termasuk ke dalam kategori tersebut yaitu mencerca di hadapan orang banyak dengan suara keras, melempar sesuatu, dan membeberkan kesalahannya di depan semua orang (Kementerian Kesehatan, Ketenagakerjaan, dan Kesejahteraan dalam Hsio, 2015: 186). Hal ini dapat dilihat dalam data (14) yang menunjukkan perlakuan Hiyama yang kasar kepada Kazuki di lingkungan kerja.

Terakhir, data (15) masuk dalam kategori pawahara keempat, yaitu menugaskan pekerjaan secara berlebihan. Dalam data (15) dapat dilihat bahwa saat hendak pulang, Kazuki mendapatkan pekerjaan tambahan yang kapasitasnya cukup banyak. Hal ini mirip dengan salah kasus yang termasuk ke dalam kategori pawahara keempat, yaitu mendapat pekerjaan yang berat tepat sebelum jam kerja berakhir (Kementerian Kesehatan, Ketenagakerjaan, dan Kesejahteraan dalam Hsio, 2015: 187).
Dengan demikian, sistem denotasi dari ketiga data menunjukkan bahwa Kazuki mengalami pawahara. Lalu, bila dikaitkan dengan konteks sosial yang terjadi, maka sistem konotasi yang terbentuk menunjukkan bahwa kasus pawahara dapat terjadi pada pekerja wanita. Untuk lebih jelasnya, lihat bagan 7 .

Bagan 7. Sistem konotasi data (13), data (14), dan data (15).

\begin{tabular}{|c|c|c|c|}
\hline \multirow[b]{2}{*}{ Konotasi } & \multicolumn{2}{|c|}{ Ekspresi } & Isi \\
\hline & \multicolumn{2}{|c|}{$\begin{array}{l}\text { Kazuki mengalami } \\
\text { pawahara di tempat } \\
\text { kerjanya. }\end{array}$} & $\begin{array}{l}\text { Kasus } \\
\text { pawahara } \\
\text { dapat } \\
\text { terjadi } \\
\text { pada } \\
\text { pekerja } \\
\text { wanita. }\end{array}$ \\
\hline \multirow{4}{*}{ Denotasi } & Ekspresi & Isi & \\
\hline & $\begin{array}{l}\text { Cuplikan } \\
\text { adegan } \\
\text { dalam } \\
\text { pisode } 3 \\
\text { menit } \\
43.42 .\end{array}$ & $\begin{array}{l}\text { Kazuki } \\
\text { menerima } \\
\text { pengabaian } \\
\text { dari rekan } \\
\text { kerjanya. }\end{array}$ & \\
\hline & $\begin{array}{l}\text { Cuplikan } \\
\text { adegan } \\
\text { dalam } \\
\text { episode } \\
4 \text { menit } \\
03.09 .\end{array}$ & $\begin{array}{l}\text { Hiyama } \\
\text { melemparkan } \\
\text { kertas } \\
\text { laporan ke } \\
\text { arah Kazuki. }\end{array}$ & \\
\hline & $\begin{array}{l}\text { Cuplikan } \\
\text { adegan } \\
\text { dalam } \\
\text { episode } \\
4 \text { menit } \\
12.22 .\end{array}$ & $\begin{array}{l}\text { Kazuki } \\
\text { diberikan } \\
\text { pekerjaan } \\
\text { baru tepat } \\
\text { sebelum ia } \\
\text { pulang. }\end{array}$ & \\
\hline
\end{tabular}

\section{PEMBAHASAN}

Dalam hasil penelitian, terdapat 15 data yang dianalisis menggunakan pendekatan semiotik Roland Barthes. Kelima belas data tersebut dikelompokkan menjadi tujuh kelompok berdasarkan kesamaan dalam sistem denotasi yang terkandung di dalamnya. Masing-masing kelompok data kemudian dianalisis untuk 
menemukan sistem konotasi yang direpresentasikan oleh data-data tersebut.

Pada kelompok data pertama yang terdiri dari data (1) dan data (2), sistem konotasi yang terkandung di dalamnya menunjukkan bahwa populasi pekerja wanita lebih sedikit daripada laki-laki. Hal ini terjadi karena ada kaitannya dengan masa kerja wanita yang lebih pendek daripada laki-laki. Menurut Belarmino dan Roberts (2019: 279), ketika sudah menikah, wanita dituntut untuk berhenti bekerja demi mengurus anak. Oleh karena itu, laki-laki memiliki peluang lebih besar untuk direkrut karena mereka bisa bekerja lebih lama daripada wanita.

Alasan serupa juga menjadi faktor mengapa populasi wanita dalam posisi managerial sedikit. Menurut Nemoto (2016: 12), promosi jabatan akan diberikan jika seorang pegawai telah bekerja selama beberapa tahunbiasanya promosi jabatan akan diberikan saat pegawai tersebut berusia menjelang akhir 30-an. Hal ini jelas menyulitkan pekerja wanita yang memiliki ekspektasi peran gender dalam ranah domestik, seperti membesarkan anak dan mengurus rumah.

Lalu, sistem konotasi pada kelompok data kedua yang terdiri dari data (3) dan data (4) menunjukkan bahwa meskipun memiliki kemampuan yang baik, kedudukan wanita hanyalah sebagai pihak yang membantu lakilaki. Menurut Belarmino dan Roberts (2019: 278), dalam berhubungan dengan laki-laki, wanita harus memposisikan diri sebagai pihak yang membantu. Hal inilah yang kemudian direpresentasikan oleh data (3) dan data (4) yang memperlihatkan bahwa Kazuki mengambil peran sebagai "penjembatan" antara pegawai Yoichi Bussan-Ichinose dan Yuki-dan klien asing, bukan sebagai aktor utama dalam situasi tersebut.

Kemudian, pada kelompok data ketiga yang terdiri dari data (5), data (6), dan data (7), sistem konotasi yang terkandung di dalamnya menunjukkan bahwa pekerja wanita merupakan office flowers yang dituntut untuk mengerjakan pekerjaan kasar. Hal ini karena pekerja wanita dituntut untuk memberikan dukungan kepada pekerja laki-laki dan membuat mereka merasa nyaman agar mereka dapat bekerja dengan baik (Belarmino dan Roberts, 2019: 279; Dinca dkk., 2017: 612). Fenomena ini terjadi karena adanya stereotip peran gender tradisional yang masih berlaku di masyarakat Jepang, yaitu wanita berperan sebagai subordinat bagi laki-laki (Belarmino dan Roberts, 2019: 282).

Lalu, pada kelompok data keempat yang terdiri dari data (8), sistem konotasi yang ada menunjukkan bahwa wanita cenderung tidak akan disukai jika ia lebih hebat atau lebih superior daripada laki-laki. Sebab, menurut Belarmino dan Roberts (2019: 284), wanita dituntut untuk memiliki peran yang lebih rendah daripada laki-laki. Terlebih lagi, mereka harus tetap bersikap rendah hati agar laki-laki tidak merasa tersaingi (Poerwandari dkk. 2014: 110).

Selanjutnya, sistem konotasi yang terdapat pada kelompok data kelima yang terdiri dari data (9) dan data (10) menunjukkan bahwa pekerja wanita harus berjuang dalam ranah publik sekaligus domestik tanpa bantuan yang cukup dari pasangan. Menurut Dalton dalam Belarmino dan Roberts (2019: 274), terdapat kecenderungan dalam ekspektasi peran gender tradisional di kalangan masyarakat Jepang, yaitu wanita menjadi seorang ibu rumah tangga sekaligus seorang ibu, sekalipun ia bekerja di luar rumah. Selain itu, Belarmino dan Roberts juga menjelaskan bahwa peran yang diemban oleh wanita modern di Jepang sangat sulit karena mereka harus menyeimbangkan nilainilai pribadi, tradisional, dan komunitas. $\mathrm{Hal}$ inilah yang menjadi alasan bahwa wanita yang bekerja di luar rumah akan dihadapkan pada konsekuensi tanggung jawab ganda, yaitu di lingkungan kerja dan di rumah.

Selain itu, menurut Grant dalam Villa (2019: 67), banyak laki-laki yang mengorbankan waktu bersama keluarga demi pekerjaan. Mereka juga diketahui jarang mengambil cuti demi urusan keluarga karena takut mendapat kritik dari rekan kerjanya. Hal inilah yang kemudian menjadi permasalahan yang harus dihadapi oleh ibu yang bekerja-mereka tidak mendapatkan dukungan yang cukup dari pasangan mereka. Maka dari itu, dapat dikatakan bahwa pekerja laki-laki hanya bertanggung jawab di ranah publik, sedangkan pekerja wanita bertanggung jawab di ranah publik sekaligus ranah domestik.

Lalu, kelompok data keenam yang terdiri dari data (11) dan data (12) mengandung sistem konotasi yang menunjukkan bahwa kasus sekuhara dapat menimpa wanita di tempat kerja. 
Menurut Efron (1999: 134), sekuhara terjadi sebagai akibat dari budaya, nilai, dan adat istiadat. Lebih lanjut, Huen (2007: 813) menjelaskan bahwa penyebab terjadinya kasus sekuhara berkaitan dengan konsep wa (harmoni) dalam masyarakat Jepang.

Menurut Huen (2007: 813), dalam perusahaan-perusahaan Jepang, kegiatan seperti rekreasi, perjamuan makan, dan wisata menginap semalam dilakukan untuk menumbuhkan wa dan menjaga hubungan baik antarpekerja. Namun, tidak dapat dipungkiri adanya risiko terjadinya kasus sekuhara dalam kegiatan tersebut. Sebab, dalam ranah pekerjaan, candaan yang berbau seksual dianggap sebagai cara untuk menciptakan wa di lingkungan kerja. Maka dari itu, pekerja wanita tidak bisa menghindarkan diri dari tindak sekuhara karena dianggap akan menghancurkan keharmonisan di tempat kerja.

Terakhir, sistem konotasi yang terdapat pada kelompok data ketujuh yang terdiri dari data (13), data (14), dan data (15), menunjukkan bahwa kasus pawahara dapat terjadi pada pekerja wanita. Kasus pawahara terjadi akibat perubahan dunia bisnis dan lingkungan kerja di Jepang (Naito, 2013: 117; Roberts, 2014: 22). Perubahan tersebut mencakup perubahan globalisasi dan teknologi, perubahan perilaku staf muda terhadap pekerjaan, dan cara mereka berkomunikasi serta berinteraksi dengan atasan mereka (Roberts, 2014: 22).

Menurut Hsiao (2015: 185), dalam kasus pawahara, tindakan yang dilakukan tidak selalu disengaja. Selain itu, korban dari tindak pawahara merupakan pihak yang memiliki kedudukan yang lebih rendah daripada pelaku. Dalam salah satu kasus pawahara yang dikaji oleh Roberts (2014: 27), korban merupakan pekerja wanita di sebuah perusahaan penerbitan di Jepang. Menurut korban, ia menjadi target tindak pawahara karena ia adalah wanita-target paling lemah. Hal ini menunjukkan bahwa dalam lingkungan kerja di Jepang, terdapat anggapan bahwa wanita merupakan pihak yang lemah dan memiliki kedudukan yang lebih rendah bila dibandingkan dengan pekerja lakilaki.

Berdasarkan penjabaran ketujuh kelompok data tersebut, maka dapat ditarik pola-pola yang menggambarkan representasi pekerja wanita dalam serial drama Hope: Kitai
Zero no Shinnyu Shain. Pola pertama mengacu pada kelompok data pertama dan kelompok data kelima. Pola yang terbentuk dari kedua kelompok data tersebut menunjukkan bahwa peran gender utama bagi seorang wanita adalah berada di ranah domestik. Hal ini terbukti dari tingkat populasi pekerja wanita yang rendah dan bagaimana pekerja wanita tidak bisa melepaskan tanggung jawabnya di ranah domestik meskipun ia sudah berkecimpung di ranah publik.

Lalu, pola kedua mengacu pada kelompok data kedua dan kelompok data ketiga. Kedua kelompok data tersebut sama-sama menunjukkan bahwa wanita berperan sebagai pihak yang mendukung laki-laki. Hal ini dapat dilihat dari adanya stereotip peran gender yang menuntut wanita untuk membantu dan melayani laki-laki. Stereotip peran gender tersebut menjadi latar belakang adanya fenomena office flowers dalam lingkungan kerja di Jepang.

Terakhir, pola ketiga mengacu pada kelompok data keempat, kelompok data keenam, dan kelompok data ketujuh. Ketiga data tersebut memperlihatkan bahwa pekerja wanita merupakan pihak subordinat yang kedudukannya di bawah laki-laki. Pada data keempat, sistem konotasi yang terbentuk menunjukkan bahwa wanita yang lebih superior dari laki-laki tidak akan disukai. Sebab, superioritas tersebut dapat mengancam posisi laki-laki sebagai pihak yang memiliki kedudukan lebih tinggi daripada wanita. Lalu, kelompok data keenam dan kelompok data ketujuh menunjukkan bahwa wanita memiliki risiko mengalami tindak pelecehan, baik itu sekuhara maupun pawahara. Kedudukan wanita yang lebih rendah dan statusnya sebagai pihak yang subordinat menjadikannya target dalam tindak pelecehan tersebut.

\section{KESIMPULAN}

Saat ini, sistem ketenagakerjaan di Jepang dihadapkan pada persoalan mengenai isu gender. Hal ini terjadi karena adanya ketidaksetaraan antara pekerja laki-laki dan pekerja wanita. Fenomena ketidaksetaraan tersebut kemudian direfleksikan oleh media Jepang melalui penayangan serial drama Hope: Kitai Zero no Shinnyu Shain. Dalam serial drama 
tersebut, penokohan Kazuki Akane dan Shiraishi Ryoko merepresentasikan pekerja wanita di Jepang.

Berdasarkan analisis data yang dilakukan menggunakan pendekatan semiotik Roland Barthes, ditemukan pola-pola yang menggambarkan representasi pekerja wanita dalam serial drama Hope: Kitai Zero no Shinnyu Shain. Pola-pola tersebut antara lain 1) peran gender utama bagi seorang wanita adalah berada di ranah domestik; 2) wanita berperan sebagai pihak yang mendukung laki-laki; 3) wanita merupakan pihak subordinat yang memiliki kedudukan lebih rendah dibandingkan laki-laki. Ketiga pola tersebut menunjukkan bahwa peran gender yang dimiliki oleh wanita Jepang sangat berbeda dari peran gender laki-laki. Dengan demikian, representasi pekerja wanita dalam serial drama Hope: Kitai Zero no Shinnyu Shain merefleksikan adanya ketidaksetaraan gender antara pekerja laki-laki dan pekerja wanita di Jepang.

\section{DAFTAR PUSTAKA}

Arai, Misako \& Sebastien Lechevalier. 2005. Gender Inequality within the Segmentation of the Japanese Labor Market?: Considering Gender in the Analysis of Toyotist Salary Ratios. Le Mouvement Social, 20(1), 121-152.

AsianWiki. Hope: Kitai Zero no Shinnyu Shain. Diakses di http://asianwiki.com/Hope:_Kitai_Zero _no_Shinnyu_Shain pada 16 Agustus 2020.

Assmann, Stephanie. 2014. Gender Equality in Japan: The Equal Employment Opportunity Law Revisited. Japan Focus: The Asia-Pacific Journal, 12(2), 1-24.

Barret, Kelly. 2004. Women in the Workplace: Sexual Discrimination in Japan. Human Rights Brief, 11(2), 5-8.

Barthes, Roland. 1986. Elements of Semiology (11th ed.). New York: Hill and Wang.

Belarmino, Melanie \& Melinda R. Roberts. 2019. Japanese Gender Role Expectation and Attitudes: A Qualitative Analysis for
Gender Inequality. Journal of International Women's Studies, 20(7), 272-288.

Chandler, Daniel. 2007. Semiotics: The Basics (2nd ed.). New York: Routledge.

Dinca, Violeta Mihaela, Teodora Floricel, dan Monica Zottu. 2017. Japanese Women in the Contemporary Society. Proceedings of the 11th International Conference of Business Excellence. 607-615.

Efron, Jacqueline M. 1999. The Transnational Application of Sexual Harassment Laws: A Cultural Barrier in Japan. University of Pennsylvania Journal of International Law, 20(1), 133-177.

Fukutake, Tadashi. 1989. The Japanese Social Structure: Its Evolution in the Modern Century (2nd ed.). Jepang: University of Tokyo Press.

Giddens, Anthony. 2006. Sociology (5th ed.). UK: Polity Press.

Gordon, Andrew. 2003. A Modern History of Japan: From Tokugawa Times to the Present. New York: Oxford University Press.

Hall, Stuart. 2009. Representation: Cultural Representations and Signifying Practices. UK: Sage Publications.

Hoed, Benny H. 2014. Semiotik dan Dinamika Sosial Budaya. Depok: Komunitas Bambu.

Hsio, Phillip. 2015. Power Harassment: The Tort of Workplace Bullying in Japan. Pasific Basin Law Journal, 32(2), 182-201.

Huen, Yuki W. P. 2007. Workplace Sexual Harassment in Japan: A Review of Combating Measures Taken. Asian Survey, 47(5), 811-827.

MyDramaList. Hope - Kitai Zero no Shinnyu Shain (2016). Diakses di https://mydramalist.com/18517-hopekitai-zero-no-shinnyu-shain pada 16 Agustus 2020.

Naito, Shino. 2013. Workplace Bullying in Japan. JILPT International Seminar 2013: Workplace Bullying and Harassment, Tokyo: 27-28 Februari 2013. Hlm. 113-133. 
Nemoto, Kumiko. 2016. Too Few Women at the Top: The Persistence of Inequality in Japan. New York: Cornell University Press.

Poerwandari, Elizabeth K., Tara De Thouars, dan Hirano Keiko. 2014. Gender Construction in Five Japanese Serial Dramas: Fantasy and the Real Lives of Japanese Youth. Asian Journal of Women's Studies 20, no. 2: 97-132.

Roberts, Glenda S.2014. 'Power Harassment' and the Workplace Environment in Japan: The Evolution of the Concept Amidst Uncertain Times. Journal of Asia-Pacific Studies, 22(Maret), 21-35.

Shinotsuka, Eiko. 1994. Women Workers in Japan: Past, Present, Future. Dalam J. Gelb \& M. L. Palley (Ed.), Women of Japan and Korea: Continuity and Change (hlm. 95119). Philadelphia: Temple University Press.

Sugimoto, Yoshio. 1997. An Introduction to Japanese Society. Cambridge: Cambridge University Press.

Sunarto, Kamanto. 1993. Pengantar Sosiologi. Jakarta: Lembaga Penerbit Fakultas Ekonomi Universitas Indonesia.

Turner, Bryan S. (Ed.). 2006. The Cambridge Dictionary of Sociology. New York: Cambridge University Press.

Villa, Luisa Fernanda. 2019. Classic Patriarchal Values and Their Effects on Working Japanese Women. Revista Mundo Asia Pacifico, 8(14), 60-75.

Watanabe, Yoko. 2011. Women, Work, and Education in Japan: An Observation of the Career Life and the Social Role of Yayoi Yoshioka. Lifelong Education and Libraries, 11, 25-46.

World Bank. Labor Force, Female (\% of Total Labor Force) - Japan. (21 Juni 2020). Diakses di https://data.worldbank.org/indicator/S L.TLF.TOTL.FE.ZS?locations=JP pada 17 Agustus 2020.

World Bank. Labor Force Partisipation Rate, Female (\% of Female Population Ages 15+) (Modeled ILO Estimate) - Japan. (21 Juni 2020). Diakses di https://data.worldbank.org/indicator/sl. tlf.cact.fe.zs?name_desc $=$ false\&locations =JP pada 17 Agustus 2020 .

World Bank. Labor Force Partisipation Rate, Male (\% of Male Population Ages 15+) (Modeled ILO Estimate) - Japan. (21 Juni 2020). Diakses https://data.worldbank.org/indicator/S L.TLF.CACT.MA.ZS?locations=JP\&na me_desc $=$ false pada 17 Agustus 2020.

World Bank. Part Time Employment, Female (\% of Total Female Employment) - Japan. (21 Juni 2020). Diakses di https://data.worldbank.org/indicator/S L.TLF.PART.FE.ZS?locations $=J P$ pada 3 September 2020.

Wulandari, Zuriyatus S. dan Putri Elsy. 2018. Matahara Mondai dan Keinginan Wanita Muda Jepang untuk Bekerja dan Memiliki Anak. Japanology, 6(2), 179-192. 